\section{Children's height and weight centile charts}

Sir,

The use of height and weight centile charts in evaluating the growth status and progress of children is a fundamental component of competent paediatric practice. However, in many centres the reference charts in use are those produced by Tanner and Whitehouse, dated 1959. Not all paediatricians will be familiar with the more recent version of 1966 , but it seems to be of value to point out the remarkable differences between these two sets of charts. This is partly attributable to the advancing age of puberty, but is more striking for the weight values than for height for much of later childhood. The 97 th centile weight lines in 1959 correspond to positions close to the 90 th centile in 1966. Without dwelling on the possible implications of this with regard to the increasing incidence of obesity and the realization that average need not necessarily be optimal, it seems advisable for a general change to the use of the more recent charts. The next edition, which must soon be due, will be eagerly awaited and may reveal even more disquieting trends.

J. M. H. BUCKLER Department of Paediatrics, University of Leeds, 27 Blundell Street, Leeds LS1 3ET.

\section{Acute intermittent porphyria in childhood: a neglected diagnosis?}

Sir,

It was with great interest that we read the report under this heading by Dr. Naomi Barclay (1974). We would like to support her conclusions and mention that we previously reported the clinical, biochemical, and family findings in a 5-year-old boy with acute intermittent porphyria (AIP) (KreimerBirnbaum, Mosovich, and Bannerman, 1971). He presented with convulsions, and other features, as in adults, included abdominal pain, hypertension, and electrolyte disturbances. There were greatly increased levels of $\delta$-amino-levulinic acid, porphobilinogen, and porphyrins in the urine. At that time we were unable to determine by urine tests and glycine loading tests who else in his family was a latent carrier of the AIP gene.
More recently we have studied the children of a man who has had repeated active episodes of AIP (Table), the W. family (Kreimer-Birnbaum and Bannerman, 1974). The propositus' 5-year-old daughter has had recurrent convulsions, usually in association with upper respiratory infections, and classified as febrile convulsions. By assaying red cell uroporphyrinogen synthase (URO-S) (Strand et al., 1972; Granick et al., 1972), the enzyme that converts porphobilinogen to uroporphyrinogen, by a micromethod, it was shown that this child and her brother aged 6, like their father, have low URO-S levels (Table) and are probably latent carriers of the AIP gene. The little girl's convulsions may therefore be wholly or partly due to AIP.

In order to detect carriers early in life by the presence of low URO-S levels, we have extended our studies to cultured amniotic fluid cells, and cord blood (KreimerBirnbaum, Rusnak, and Kaplan, 1974). There is measureable URO-S activity in cultured amniotic cells, but the range of activity is very large. Methodological improvements are in progress so that it may become possible to make an antenatal diagnosis of latent AIP. Cord red cells from apparently normal babies show a mean level of $87.6 \mathrm{nmol}$ porphyrin formed per $\mathrm{ml}$ red blood cells per hour (SD 16.5). This is twice as high as the mean value for control adult blood (Table). The URO-S level of cord blood cells of the newborn in the W. family was 54.8 units, which is below the lowest value of normal range. At 4 months of age (with a fetal $\mathrm{Hb}$ level of $12 \mathrm{~g} / \mathrm{dl}$ ) the URO-S has declined to 23.5 units. In a few months, as this child's blood loses its fetal characteristics associated with very high levels of URO-S activity (Kreimer-Birnbaum et al., 1974), it may be possible to define her genotype.

It is of the utmost importance that paediatricians recognize the symptomatology of AIP and include it in their differential diagnosis, and that known porphyrogenic anticonvulsants, such as the barbiturates, should not be too readily prescribed. Family history and the recently developed biochemical tests in addition to the usual urine tests should help in the early diagnosis of AIP.

MARTHA KREIMER-BIRNBAUM
and ROBIN M. BANNERMAN
Department of Medicine,
Medical Genetics Unit,
Buffalo General Hospital,
Buffalo, New York 14203, U.S.A.

REFERENCES

Barclay, N. (1974). Acute intermittent porphyria in childhood: a neglected diagnosis ? Archives of Disease in Childhood, 49, 404.

Kreimer-Birnbaum, M., and Bannerman, R. M. (1974). Uroporphyrinogen synthase: studies in normal and porphyric families. 
TABLE

Levels of uroporphyrinogen synthase (URO-S)

\begin{tabular}{|c|c|c|}
\hline & Diagnosis & $\begin{array}{l}\text { URO-S (nmol porphyrin/ml } \\
\text { red blood cell per } \mathrm{h} \text { ) }\end{array}$ \\
\hline $\begin{array}{l}\text { W. family (age) } \\
\text { Father-propositus (40) } \\
\text { Mother (30) } \\
\text { Daughter (7) } \\
\text { Son (6) } \\
\text { Daughter (5) } \\
\text { Daughter } \\
\quad \text { Birth } \\
4 \mathrm{~m} \\
\text { Control levels (mean } \pm \text { SD) } \\
20 \text { yrs and over }(\text { no. }=19) \\
1 \text { to } 15 \text { yrs (no. }=20) \\
\text { Cord bloods (no. }=31 \text { ) }\end{array}$ & $\begin{array}{l}\text { AIP, acute attacks } \\
\text { Normal } \\
\text { Normal } \\
\text { ? AIP, latent } \\
\text { ? AIP, latent } \\
\text { ? }\end{array}$ & $\begin{array}{l}15 \cdot 7 \\
33 \cdot 2 \\
26 \cdot 2 \\
14 \cdot 3 \\
17 \cdot 8 \\
54 \cdot 8 \\
23 \cdot 5 \\
\\
37 \cdot 9 \pm 7 \cdot 7 \\
38 \cdot 9 \pm 7 \cdot 4 \\
87 \cdot 6 \pm 15 \cdot 6\end{array}$ \\
\hline
\end{tabular}

^From Kreimer-Birnbaum et al. (1974).

Ontario-New York Meeting of the American College of Physicians, October, 1974. (In preparation.)

Kreimer-Birnbaum, M., Mosovich, L. L., and Bannerman, R. M. (1971). Acute intermittent porphyria: a clinical, biochemical and family study. Fournal of Medicine (Basle), 2, 149.

Kreimer-Birnbaum, M., Rusnak, P., and Kaplan, P. (1974). Uroporphyrinogen synthase (URO-S). Neonatal and possible fetal detection of acute intermittent porphyria. XV International Congress of Hematology, Jerusalem, September, 1974, p. 459. (Submitted for publication.) (Abstr.)
Granick, S., Sassa, S., Granick, J. L., Levere, R. D., and Kappas, A. (1972). Assay for porphyrins, $\delta$-amino levulinic acid dehydratase and porphyrinogen synthetase in microfilter samples of whole blood. Applications to metabolic defects involving the Heme pathway. Proceedings of the National Academy of Sciences, U.S.A., 69, 2381.

Strand, L. J., Meyer, U. A., Felsher, B. F., Redeker, A. G., and Marver, H. S. (1972). Decreased red cell uroporphyrinogen I synthetase activity in intermittent acute porphyria. Fournal of Clinical Investigation, 51, 2530. 